\title{
Effectiveness of the Flipped Classroom Strategy in Learning Outcomes (Bibliometric Study)
}

\author{
Thuraya Sulaiman Al-Shabibi \\ Sultan Qaboos University \\ Muscat, Oman \\ Mohammed Abdul-Karim Al-Ayasra \\ Sultan Qaboos University \\ Muscat, Oman
}

\begin{abstract}
The aim of this study is to explore the effectiveness according to the flipped classroom strategy in learning outcomes. To achieve this, the descriptive method of "bibliometric analysis" was used. It analyzed (233) scientific studies and evaluated them in a critical manner in light of the study questions, within the range of eight years (2012-2019) in order to identify the variables that these studies sought to investigate on the strategy, its impact on those variables, and the justification behind its positive impact. The study results reveal that the flipped classroom can provide students with a more interactive environment that will lead to higher learning achievement and better preparation for 21st century learning and work environments. Many of the studies targeted by the present study have analyzed the advantages and privileges of this strategy and the importance of its application in different stages of education because of its obvious results in improving the range of learning outcomes. In view of its findings, the study recommended an expansion of teachers' use of the flipped classroom strategy because of its positive impact in learning outcomes. It also suggested conducting studies on the reasons behind the lack of a clear positive impact of the strategy in some studies.
\end{abstract}

Keywords: strategy; flipped classroom; survey; bibliometric study.

\section{Introduction}

The rapid development of communication and information technologies and the spread of digital literacy among school and university students have led to the emergence of new teaching and learning systems. These technologies have resulted in innovative teaching strategies based on diverse technology tools, notably the Flipped Classroom strategy. Flipped Classroom is a form of 
integrated education that intelligently employs modern technology to provide education that meets the learner's needs in the 21st century. In this strategy the student becomes a researcher by his own when using technology effectively through learning outside the school boundaries, promoting critical thinking, self-learning, communication skills and collaborative work among students, which, all, make difference in the students' educational outcomes (Adhuwaykh, 2013).

Those interested in the teaching methods and strategies considered the flipped learning as the future of education. They perceive it as the easiest way to apply technology in education, without prejudice to the principles of traditional education that consider direct interaction, between the teacher and the learner on the one hand and the learners on the other, an essential foundation for building learning (Zohi, 2014).

Bishop and Verleger (2013, p.2) defined the flipped classroom strategy as: "An educational strategy that employs asynchronous learning by watching recorded videos for lectures and lessons, which motivate the learner to watch them as homework before coming to class. The lesson time is allocated to actively participate in problem-solving techniques collectively." This definition indicates that the flipped classroom strategy contains two types of learning activities: individualized learning outside the classroom time by watching recorded videos and collective interactive learning among learners during the lesson.

Azahrani (2015) points out that this strategy is based on flipping the learning process. Instead of receiving new concepts in the classroom and then doing homework at home, the learner receives new concepts in the flipped classroom at home by watching videos that are prepared by the teacher and that last from 5 to 10 minutes. The teacher shares these videos with the students on a Web2 site or on social networking media. They can also share video clips, multimedia, or educational games from online resources such as YouTube for Education, Khan Academy, Or TED Talk and other educational sites.

Asherman (2015) shows that when the learner follows-up the explanation of the educational material through modern technology- such as tablets or smart phones- he is able to: proceed at his own pace, pause the explanation of the material whenever he wishes to write down notes or questions about the content and then continue to display the explanation again, re-watch more than once in order to understand the material displayed, the learner can also go backward and forward to clarify certain points, or transcend a section already known. Thus, the strategy takes into account individual differences between learners, and increases their enjoyment of learning.

Adhuwaykh (2013) confirms that the role of teacher and learner is different in this strategy. The teacher is here to guide, assist and motivate. He supervises the progress of activities, tasks and projects, and provides support to learners who need more attention. As a result, the teacher can spend more time interacting with learners, and go deeper in effective and appropriate educational activities. 
In this strategy, the learner becomes an active researcher and user of technology by learning outside the classroom, fostering critical thinking, self-learning, experience building, social communication skills and collaboration to achieve 21st-century skills in education. This strategy is distinguished from other strategies and educational methods by many advantages that take into account the learner's overall needs and capabilities to achieve better learning. Thus, the flipped classroom strategy has received considerable attention in many advanced countries.

The two researchers noted the scarcity of bibliometric studies that aimed at analyzing previous studies carried out on the flipped classroom strategy. The researchers found only four bibliometric studies conducted on this strategy, including: Lundin et al. (2018) study which investigated the previous studies conducted on the flipped classroom strategy in the database (Scopus database) including (530) studies, published in the period from (2011 - 2015). The researchers analyzed the previous studies in terms of: 1-educational stages,2academic disciplines suitable for the implementation of the strategy, 3- the countries that implemented the strategy, 4- methods of data collection and 5- the needed recommendation and future research. The study found that the number of studies implemented in this strategy is growing rapidly over time, reflecting the increasing interest in the strategy. Most of these studies focused on implementing the strategy in higher education, specifically in the fields of science, technology, engineering and mathematics, and most of them were conducted in the United States. Further studies are needed to improve the practices of the strategy implementation.

The study of Zainuddin and Halili (2016) aimed at analyzing 20 previous studies carried out in the flipped classroom during the period from (2013-2015). Content analysis was used to examine methodologies, field of study, technology tools used, references cited, influences on students' learning, and challenges of the flipped classroom strategy. Descriptive analysis used frequencies and percentages. The study found that previous studies used some technology to implement the strategy as online platform. Impact analysis showed that the flipped classroom had positive impacts in students' learning such as achievement, motivation, participation, and interaction. There is a need to address some of the challenges in applying the flipped classroom by future researchers, such as the adequacy of the flipped classroom due to the poor quality of the visual lectures and the untrained teacher.

Bormann (2014) conducted an analytical study to explore the effectiveness of the flipped classroom strategy in students' participation and achievement as well as the advantages of the flipped classroom model compared to the traditional model by analyzing (19) scientific studies on the flipped classroom and assessed them critically. He targeted the scientific studies available on EBSCO and Google Scholar databases, from (2012-2014). The study concluded that this strategy was well received by students and teachers at different academic levels. The study also revealed that flipped classroom strategy has more benefits and advantages compared to its shortcomings; it also provides an interactive environment for learners and focuses on higher levels of thinking. In addition, 
students were comfortable with this strategy, and their access to information gave them more confidence to learn outside the classroom.

Bishop and Verleger (2013) conducted an analytical study on the previous studies on flipped classroom strategy. They analyzed (24) scientific studies until 2012 in terms of its objectives, methodology, tools used, target groups, activities used within and outside the lesson, and findings. The researchers concluded that most of these studies focused on the perceptions of learners about the strategy. The study also emphasized the importance of employing the flipped classroom strategy in teaching, especially in stimulating learning, and enhancing teamwork and collaborative learning values.

It is worth noting that these bibliometric studies dealt with the evaluation of the Flipped Classroom strategy in general and did not elaborate, in details, its impact on the different aspects of the learning process and the learning outcomes. This is, in specific, the focus of this study, in addition to highlighting the reasons behind the positive impact of the strategy on learning outcomes. This is what other previous bibliometric studies lack and this study came to fill.

\section{Study Problem}

Analyzing dissertations and scientific studies is important to discuss the impact of the flipped classroom strategy in various variables addressed. The researchers noticed the lack of bibliometric studies that focus on the impact of this strategy in each of the learning outcomes. Most of them did not elaborate on the positive impact of the Flipped Classroom strategy on the various educational outcome, so this study aims to fill the gap in this field by focusing on discussing the impact of the flipped classroom strategy in the variables addressed.

\section{Study Objective:}

The current study aims at reviewing the previous studies that address the flipped classroom strategy so as to investigate the effectiveness of this strategy in learning outcomes and identify the reasons for its impact in these outcomes.

\section{Study Questions:}

The study seeks to answer the following questions:

1- What is the distribution of the previous studies that addressed the flipped classroom strategy according to (year of publish, approach and samples nature, countries that conducted these studies, subjects, research tools used, statistical variables)?

2- According to the previous studies, what is the impact of using the flipped classroom strategy depending on the different variables addressed by these studies?

3- How did the previous studies explain the impact of the flipped classroom strategy in learning outcomes?

\section{Study Importance:}

This study provides a comprehensive and in-depth overview of the results of implementing the flipped classroom strategy in the educational learning process. 
The studies have shown positive results on students' performance after implementing this strategy. However, the overall view through a larger set of studies within a decade and at different study levels provides researchers and practitioners in the educational process with better indicators of the effectiveness of this educational strategy. Discussing the impact of this strategy and its effectiveness may allow teachers and supervisors to determine the usefulness of implementing this strategy in the classroom, as well as how to implement it correctly.

\section{Study Limits:}

- Data Base Limit: The study covered educational research publications published in the subject of the Flipped Classroom, through the databases available in the libraries of the University of Sultan Qaboos (ProQuest Dissertations \& Theses Global, Edu Search, Scopus database, Almanhal and Shamaa) And the studies published in scientific journals and conferences, issued in Arabic and English, amounting to (233) studies.

- Time Limit: The study covered the educational research published in the period (2012), the date of the first published study obtained by the researchers, to $(2019 .($

- Subject Limit: The study included all disciplines and courses.

\section{Study Approach:}

The study used the bibliometric descriptive analytical method. The two researchers sought to analyze the scientific studies that addressed the flipped classroom strategy. They monitored their results according to the given variables that were included and identified their impact on those variables and the justification for the positive impact of the strategy.

\section{Study Sample:}

The study population consisted of a group of studies that dealt with the strategy of the Flipped Classroom, published in Arabic and English until 2019, through the databases available in the libraries of the University of Sultan Qaboos (ProQuest Dissertations \& Theses Global, Edu Search, Scopus database, Almanhal and Shamaa) They included Ph. D. and Master thesis, a number of studies published in scientific journals and conferences, which has reached approximately (7650) study. In view of the large size of the study population, the researchers aimed at randomly selecting the sample, which consisted of (233) scientific studies

\section{Study Instrument:}

In this study, an analysis card was used to analyze the content of the studies that were reached. It contains the following:

- Define all the variables of the previous studies and research under study.

- Give one frequency to each variable (noting that one study contains a variable or more).

- Determine the outcome of the study for each variable. 
- Define the justifications for the positive impact of the strategy in the various variables.

To verify the instrument validity, it was presented to three arbitrators professors in the curricula and teaching at Sultan Qaboos University and took their comments and suggestions thereon. The instrument reliability was verified by piloting the instrument to (6) studies outside the study sample and comparing results with the results of one of the specialized researchers on the same sample. The percentage of agreement was $94 \%$.

\section{Study Results and Discussion}

To answer the first question: "What is the distribution of the previous studies that addressed the flipped classroom strategy according to (year of publish, approach and samples nature, countries that conducted these studies, subjects, research tools used, variables?)", the researchers used the analysis card to analyze, assess and classify the previous studies that addressed the flipped classroom strategy. The analysis card included: Author's name, year, country, study objective, study approach, subjects, study tools and findings. The following charts and tables illustrate the distribution of studies according to: the year, study approach, samples, countries in which studies were carried out; subjects; research tools used; and study variables. Table (1) shows the frequency and percentages of the distribution of studies according to the year.

Table 1. The frequency and percentages of the distribution of studies according to the year

\begin{tabular}{|c|c|c|}
\hline years & frequency & percentage \\
\hline 2019 & 4 & $2 \%$ \\
\hline 2018 & 48 & $21 \%$ \\
\hline 2017 & 51 & $22 \%$ \\
\hline 2016 & 53 & $23 \%$ \\
\hline 2015 & 43 & $18 \%$ \\
\hline 2014 & 21 & $9 \%$ \\
\hline 2013 & 10 & $4 \%$ \\
\hline 2012 & 3 & $1 \%$ \\
\hline total & 233 & $100 \%$ \\
\hline
\end{tabular}

Table (1) shows the recent studies that addressed the flipped classroom strategy, where the researchers found that these studies started in 2012 and that the number of these studies has increased over the years, culminating in the studies 
analyzed in 2016. Table (2) shows the frequency and percentages of the distribution of studies according to the study approach.

Table 2. The frequency and percentages of the distribution of studies according to the study approach

\begin{tabular}{|c|c|c|}
\hline Methodology & frequency & percentage \\
\hline experimental & 207 & $89 \%$ \\
\hline descriptive & 24 & $10 \%$ \\
\hline mixed & 2 & $1 \%$ \\
\hline Total & 233 & $100 \%$ \\
\hline
\end{tabular}

Table (2) shows that most studies (89\%) have used the experimental approach which is appropriate for the nature of the strategy and the variables addressed by these studies.

Table (3) shows the frequency and percentages of the distribution of studies according to the nature of the samples.

Table 3. The frequency and percentages of the distribution of studies according to the nature of the samples

\begin{tabular}{|c|c|c|}
\hline The Sample & frequency & percentage \\
\hline Students & 205 & $84 \%$ \\
\hline Teachers & 28 & $11 \%$ \\
\hline University faculty & 7 & $3 \%$ \\
\hline Studies and research & 4 & $2 \%$ \\
\hline Total & 244 & $100 \%$ \\
\hline
\end{tabular}

Table (3) shows the diversity of samples targeted by previous studies to provide a comprehensive overview of the strategy. Some studies have used more than one type of sampling, and most of them have targeted students of different educational stages. Table (4) illustrates distribution of studies according to the grades. 
Table 4. The frequency and percentages of the distribution of studies according to the grades

\begin{tabular}{|c|c|c|}
\hline Class & frequency & percentage \\
\hline Undergraduate & 100 & $42 \%$ \\
\hline Twelfth grade & 23 & $10 \%$ \\
\hline 11th grade & 19 & $8 \%$ \\
\hline Tenth grade & 25 & $11 \%$ \\
\hline Ninth grade & 17 & $7 \%$ \\
\hline Eighth grade & 18 & $8 \%$ \\
\hline Seventh grade & 11 & $5 \%$ \\
\hline Sixth grade & 12 & $5 \%$ \\
\hline fifth grade & 7 & $3 \%$ \\
\hline fourth grade & 6 & $3 \%$ \\
\hline Total & 238 & $100 \%$ \\
\hline
\end{tabular}

Table (4) shows that previous studies targeted students at different educational stages, from grade 4 to university level. Most of these studies focused on the university level, which means that the strategy can be applied at different educational levels. Table (5) shows the frequency of distribution of studies according to the countries.

Table 5. The frequency of distribution of studies according to the countries

\begin{tabular}{|c|c|c|c|c|c|}
\hline Country & frequency & percentage & Country & frequency & percentage \\
\hline USA & 75 & $32.2 \%$ & Japan & 2 & $0.9 \%$ \\
\hline Saudi & 61 & $26.2 \%$ & Emirates & 1 & $0.4 \%$ \\
\hline Egypt & 40 & $17.2 \%$ & Bahrain & 1 & $0.4 \%$ \\
\hline Jordan & 13 & $5.6 \%$ & Iraq & 1 & $0.4 \%$ \\
\hline Palestine & 6 & $2.6 \%$ & Yemen & 1 & $0.4 \%$ \\
\hline Oman & 4 & $1.7 \%$ & Iran & 1 & $0.4 \%$ \\
\hline Australia & 4 & $1.7 \%$ & Korea & 1 & $0.4 \%$ \\
\hline Turkey & 4 & $1.7 \%$ & Brazil & 1 & $0.4 \%$ \\
\hline Qatar & 3 & $1.3 \%$ & Taiwan & 1 & $0.4 \%$ \\
\hline Kuwait & 2 & $0.9 \%$ & Sweden & 1 & $0.4 \%$ \\
\hline China & 2 & $0.9 \%$ & Canada & 1 & $0.4 \%$ \\
\hline Britain & 2 & $0.9 \%$ & Malaysia & 1 & $0.4 \%$ \\
\hline
\end{tabular}




\begin{tabular}{|l|c|c|c|c|c|}
\hline Indonesia & 2 & $0.9 \%$ & Total & 233 & 100 \\
\hline Germany & 2 & $0.9 \%$ & & & \\
\hline
\end{tabular}

Table (5) shows the interest of a big number of countries in the flipped classroom strategy, However, the higher number of studies on this topic came from U.S.A, where this strategy originated - and then in Saudi Arabia and Egypt.

Table (6) presents the subjects (courses) targeted by previous studies.

Table 6. The frequency and percentages of the distribution of studies according to the specializations (courses)

\begin{tabular}{|c|c|c|}
\hline A course & frequency & percentage \\
\hline Mathematics & 50 & $23 \%$ \\
\hline Sciences & 36 & $17 \%$ \\
\hline Educational Technology & 33 & $15 \%$ \\
\hline English Language & 18 & $8 \%$ \\
\hline Arabic Language & 14 & $6 \%$ \\
\hline Social Studies & 12 & $6 \%$ \\
\hline Teaching Methods & 11 & $5 \%$ \\
\hline Various courses & 11 & $5 \%$ \\
\hline Medicine & 9 & $4 \%$ \\
\hline Islamic Education & 6 & $3 \%$ \\
\hline engineering & 5 & $2 \%$ \\
\hline Home Economics & 3 & $1 \%$ \\
\hline Physical Education & 3 & $1 \%$ \\
\hline special breeding & 3 & $1 \%$ \\
\hline Measurement and evaluation & 2 & $1 \%$ \\
\hline Business & 1 & $0 \%$ \\
\hline Kindergarten & 1 & $0 \%$ \\
\hline Total & 218 & $100 \%$ \\
\hline
\end{tabular}


Table (6) shows that this strategy has been applied more in applied science courses such as mathematics and science, in addition to technology of education. It has also been applied in human sciences courses. This means that this strategy can be applied to different subjects.

Table (7) contains the study instruments used in previous studies.

Table 7. The frequency and percentages of the distribution of studies according to the instruments

\begin{tabular}{|c|c|c|}
\hline Tools & frequency & percentage \\
\hline exam & 140 & $36 \%$ \\
\hline observation & 50 & $13 \%$ \\
\hline Questionnaire & 49 & $13 \%$ \\
\hline Measure of perceptions and trends & 40 & $10 \%$ \\
\hline Interview & 38 & $10 \%$ \\
\hline Thinking tests & 28 & $7 \%$ \\
\hline Motivational scale & 15 & $4 \%$ \\
\hline Self-efficacy scale & 10 & $3 \%$ \\
\hline Skills tests & 9 & $2 \%$ \\
\hline Self-learning scale & 6 & $2 \%$ \\
\hline Content Analysis & 4 & $1 \%$ \\
\hline Measure habits of mind & 3 & $1 \%$ \\
\hline Total & 392 & $100 \%$ \\
\hline
\end{tabular}

Table (7) shows that previous studies have used various research tools, and that a large number of studies have used more than one data collection instrument. Tests were among the most commonly used instruments, followed by observation and survey. As for the variables targeted by previous studies, Table (8) presents the frequency and percentages of the distribution of studies according to study variables. 
Table 8.The frequency and percentages of the distribution of studies according to study variables

\begin{tabular}{|c|c|c|}
\hline Variables & frequency & percentage \\
\hline achievement & 141 & $36 \%$ \\
\hline Evaluation of strategy & 53 & $13 \%$ \\
\hline Trend towards strategy & 30 & $8 \%$ \\
\hline thinking skills & 29 & $7 \%$ \\
\hline Classroom participation & 27 & $7 \%$ \\
\hline Electronic Skills & 22 & $6 \%$ \\
\hline Motivation & 18 & $5 \%$ \\
\hline Trend towards the course & 15 & $4 \%$ \\
\hline Self-efficacy & 14 & $4 \%$ \\
\hline Self-learning & 12 & $3 \%$ \\
\hline reading and writing & 9 & $2 \%$ \\
\hline Teaching skills & 7 & $2 \%$ \\
\hline Keep learning & 5 & $1 \%$ \\
\hline Performance skills & 5 & $1 \%$ \\
\hline Reduce anxiety & 4 & $1 \%$ \\
\hline Habits of mind & 3 & $1 \%$ \\
\hline Total & 394 & $100 \%$ \\
\hline
\end{tabular}

Table (8) shows the frequency and percentages of the distribution of studies according to the study variables. It shows that the previous studies targeted the impact of the flipped classroom strategy focusing on various variables, and the researchers believe that it is one of the most important learning outcomes that the educational process seeks to develop among students. It is also clear from results that academic achievement is one of the most important variables targeted by previous studies.

To answer the second question: "According to the previous studies, what is the impact of using the flipped classroom strategy depending on the different variables addressed by these studies?", the researchers analyzed the previous 
studies and assessed them using the analysis card according to the impact of the strategy in the different variables addressed by these studies. Figure (1) shows the distribution of variables according to the impact of the strategy included.

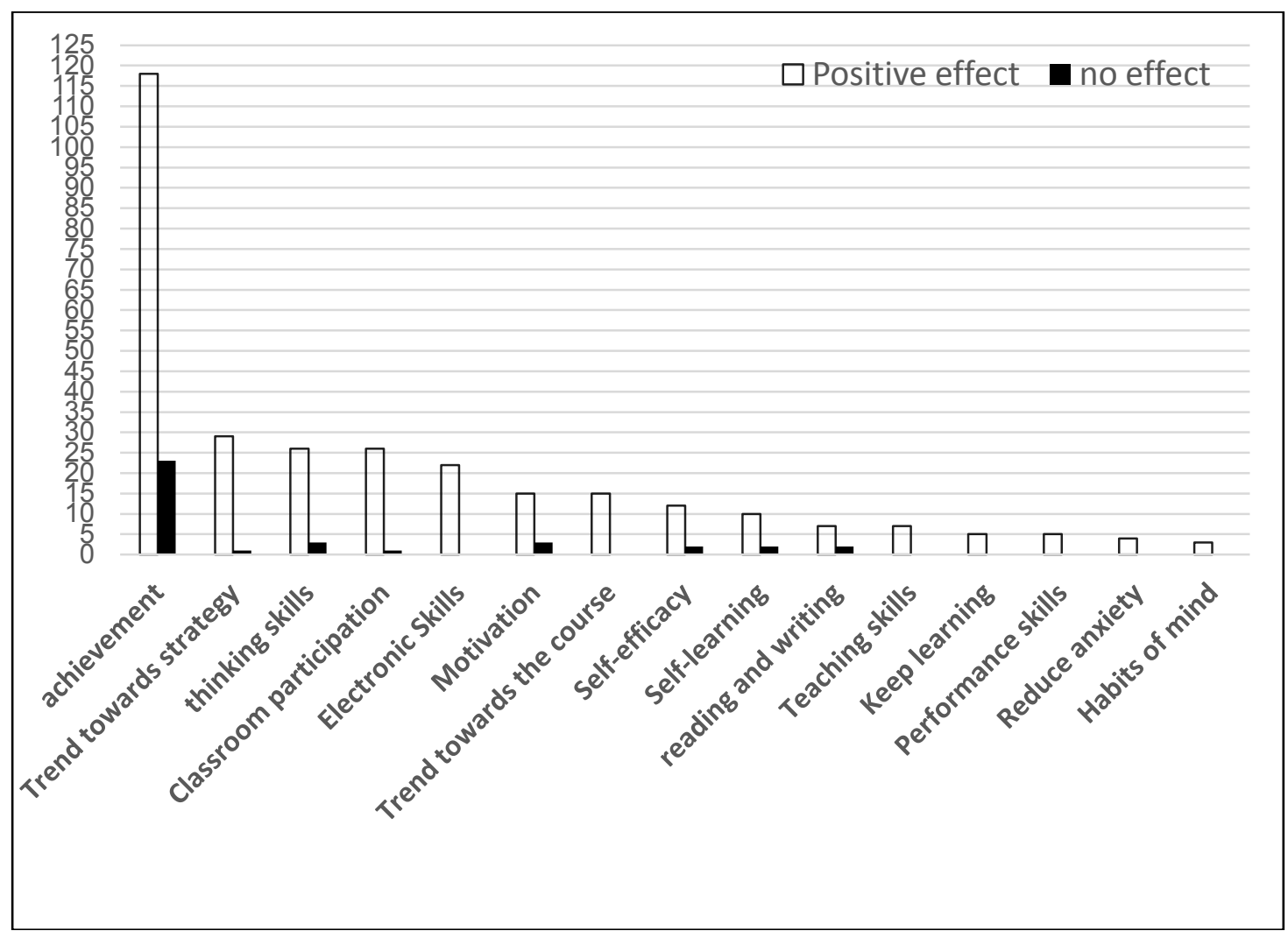

Figure 1. The distribution of variables according to the impact of the strategy

Figure (1) shows the distribution of studies according to the variables, and the impact of the strategy. The empty column indicates the positive impact of the strategy, while the black column indicates that there is no impact of the strategy. It is noted that the flipped classroom strategy has a clear positive impact in most of the variables targeted by the previous studies.

To answer the third question: " How did previous studies explain the impact of the flipped classroom strategy in learning outcomes?", the researchers analyzed the previous studies to justify the positive impact of the strategy on various variables. They found that previous studies attributed the positive impact of the strategy to the following reasons:

Students performing a number of tasks and individual activities prior to attending the lesson, including watching educational videos, writing questions they would like to give to the teacher or their classmates, which helps them spend more time for prior learning and prepare well for the lessons. Therefore, the original time of the lesson gets richer and full of discussion. The lesson time will be used for higher thinking skills to solve problems related to the subject, and debate more effectively compared to the traditional methods. 
When students watch videos before the lesson, it will enable them to prepare questions for the teacher and their colleagues in the classroom. These questions help them understand and check their comprehension. In this regard, Brame (2013) stated that reading the material prior to the lesson prepares students mentally and intellectually for the activities and applications that take place during the lesson, and that evolve around what the students have learned at home. Bergman and Sams (2014, p. 146) have emphasized, after applying this strategy, that it made it possible to make students come to the classroom with comments and questions about the subject, making them ask better questions over time and thinking more deeply about the learnt content. It also became easier to follow students individually and see if they have any misunderstandings of concepts and correct them.

Watching videos prior to the lesson helps students to feel comfortable and confident. It helps them also to overcome the fear that some students may experience as a result of traditional teaching situations and consequently making them feel unable to perform the tasks assigned to them (Shurair, 2017, p. 95).

In the flipped classroom students are encouraged to watch educational videos before class and outside the classroom at their own pace and time, according to their own learning path. Whether the student is quick or needs more time to absorb the content, he can watch the video more than once, and speed up to reach desired pace (Al-Kahili, 2015, p. 48).

Watching these educational videos through mobile devices or computers has made it possible for students to be more involved in the educational process. In addition, linking the educational materials to the internet and social networking media (WhatsApp, Facebook) responds to students' needs and interests in the current time. Regular archiving of videos helps students learn, practice, and go back to videos when needed and during preparing for exams.

As the feedback provided by the teacher to his students is the main material for learning according to the flipped classroom strategy (Sherman, 2015, p. 224), it is expected that providing feedback to the students - on a continuous and direct basis, individually and collectively, during classroom activities, quizzes and classroom assignments - has had a significant impact in this aspect following this strategy.

When students are introduced to new experiences and concepts using a new strategy that is stimulating them mentality and encouraging them to participate in discussion and interact with activities, it affects positively on students. They become more active, enjoy doing activities and love what they learn. The strategy also facilitates the learning process and enhances students' self-concept and confidence.

Because the flipped classroom strategy is based on other concepts and methods such as active learning, in which the student is at the center of the learning process, it became prominent how important is the student's role. The learner is perceived as an active learner, participant and collaborator, who actively 
participates in the activities and tasks assigned to him. On the other hand, the teacher's role in active learning is to direct, guide, facilitate and manage the learning process towards achieving the desired goals (Hamdallah, 2016, p. 51). This strategy focuses on Bloom's taxonomy, where students work on lower cognitive levels (remember, and understanding) before the lesson during watching the educational video. On the other hand, students focus on the higher cognitive levels (application, analysis, and assessment) in the lesson, during the implementation of classroom activities and exercises, and during the activation of active learning strategies, where the students receive support from their teacher and peers (Eid, 2017, p. 311).

Using the flipped classroom strategy helps to optimize the teacher's time during and outside the classroom (Johnson \& Walvoord, 1998, 30). The lesson is transformed into a training workshop through interactive activities, work papers, and group work that the teacher applies. In these activities and worksheets, the teacher answers students' questions, discusses with them, confirms their true information and corrects the wrong ones, and provides appropriate support to those who have not reached the required level. This strategy provides the teacher with more time to interact with students, use higher thinking levels to solve problems related to the subject, and discuss with them effectively during the lesson rather than lecturing in class and listening to the explanation. Thus, allowing students to understand the lesson more deeply. Furthermore, the lesson time will be allocated to further enrichment, discussion, communication, cooperation, consultation and constructive dialogue under the teacher direction and guidance. This is in line with Bergman and Sams (2012, p. 93) suggesting that the flipped classroom environment increases the lesson time, where the teacher is able to implement a large number of educational tasks.

The flipped classroom strategy plays a major role in minimizing the gap between the theoretical study of science and knowledge and its practical aspect in real life (Ashami, 2018, p. 53). It helps to link theoretical study with practical application, by examining the theoretical and cognitive content prior to the lesson through watching videos. Furthermore, it emphasizes the application aspect during the lesson through individual and group activities, and active learning strategies, which may play a role in emphasizing the knowledge acquired by students.

This strategy uses video technology for optimal use; it is effective and positive for its features and benefits. This technology is thrilling, facilitates following-up and focuses student's attention, with the ability to quickly introduce the lesson to the students making them motivated to watch the educational content on screen. At the same time, it combines audio, image, and motion. The senses of sight and hearing participate in the reception of the cognitive content, which helps to increase students' focus on concepts, receive the cognitive content, and continue to follow the lesson to its end, as indicated by Ibrahim (2017, p. 458). Providing the learning content to students outside the classroom and making it available online throughout the semester enables them to see and understand all the lessons, even if some students were not able to attend one of the classes for any reason (Hawas, 2015, p. 273). 
This strategy also contributes to the maintenance of the learning process even after the end of the study time, through practicing after-class activities, which aims to help students reach the proficiency level (Abdel Barr, 2017, p. 45).

In addition, this strategy takes into consideration the individual differences among students. Each student learns according to his own ability and speed, away from the usual educational situation. During the lesson, the teacher helps the students who have not reached the required level. The rest of the students are given additional training and enrichment activities (AL-Kurd, 2017, p. 16).

\section{Conclusion and recommendations}

The study aimed at revealing the impact of the flipped classroom strategy in learning outcomes through reviewing previous studies. The study showed that the previous studies targeted the impact of the flipped classroom strategy in many variables. The researchers believe that it is one of the most important learning outcomes that the educational process seeks to develop among students. The study concluded that the flipped classroom strategy has a positive impact in most of the variables targeted by previous studies, including: academic achievement, attitudes, classroom participation, thinking skills development, motivation for learning, self-learning, and anxiety reduction. Therefore, the study recommends expanding the use of the flipped classroom strategy by teachers because of its positive impact in promoting various aspects of the educational process. The study also suggests conducting other studies on assessing the effectiveness of the flipped classroom strategy from the point of view of teachers, learners and parents, and the reasons behind the lack of a clear positive impact of the strategy in some studies.

\section{References}

Abdul Ber, A. M. (2017). A proposed program based on inverted learning to develop the components of the mathematical structure and motivation towards learning among the female teacher students in the kindergarten stage. Journal of Mathematics Education, 20(8), 6- 56.

Adhuwaykh, N. (2013). Educational teaching method for schools: The Concept of Flipped Classroom. Retrieved on 20/1/2016 from: http://aljubailtoday.com.sa/2013/10/10/31871.html

Al-Kahili, I. S. (2015). Effectiveness of flipped classroom in education. Almadinat Almunwrat: Dar Alzaman

AL-Kurd, A. A. (2017). Impact of Using Flipped Classrooms on Developing the Skill of Mathematical Problem Solving and Mathematical Communication among Female Ninth Graders in Gaza. Unpublished M.A. thesis, Islamic University, Gaza.

Ashami, Kh. M. (2018). The Effectiveness of Using the Flipped Learning Strategy to Acquire Physics Concepts among Grade 9 Students and their Attitudes Toward Learning. Unpublished M.A. thesis, Al-Bayt University, Jordan.

Asherman, A. A. (2015). Blended Learning and Flipped Learning. Jordan: Dar almasirah.

Azahrani, A. M. (2015). Effectiveness of the Flipped Classroom Strategy in Developing the Level of Cognitive Achievement of the E-Learning Course Among the Students of the Faculty of Education, King Abdulaziz University. Journal of the Faculty of Education, 162(1), 1-30. 
Bergmann, J., \& Sams, A. (2012). Flip Your Classroom: Reach Every Student in Every Class Every Day. Washington; ISTE. doi.org/10.1177/073989131401100120

Bishop, J. L., \& Verleger, M. A. (2013). The Flipped Classroom: A Survey of the Research. Paper presented at the 120th ASEE Annual Conference \& Exposition, 23-26/ 6/ 2013, Atlanta, Georgia.

Bormann, J. (2014). Affordances of Flipped Learning and its Effects on Student Engagement and Achievement. Unpublished M.A. thesis, University of Northern IOWA.

Brame, C. (2013). Flipping the classroom. Vanderbilt University Center for Teaching. Retrieved [10 March 2018] from http://cft.vanderbilt.edu/guides-sub-pages/flippingthe-classroom/.

Eid, S. M. (2017). The Effectiveness of the Flipped Classroom Strategy in Teaching Science Teaching Methods Course for Developing the Academic Achievement and the Attitudes Toward Science Teaching Among Female Student Teachers. Journal of Faculty of Education, 33(8), 267-334.

Hamdallah, A. F. (2016). The Impact of Using Flipped Learning Strategy in Developing Inductive Thinking among Grade 8 Students in the Arabic Grammar Course. Unpublished M.A. thesis, Middle East University, Jordan.

Hawas, N. Y. (2015). Effectiveness of using the flipped classroom strategy in developing classroom interaction skills to teach Arabic grammar for second grade students. Arab Studies in Education and Psychology, (62), 249-277.

Ibrahim, A. M. (2017). The effectiveness of teaching general science course using the flipped classroom strategy in the developing cognitive achievement and the scientific added value among Faculty of Education students. Journal of Educational and Psychological Sciences, 18(4), 423- 471.

Johnson, J. \& Walvoord, E. (1998). Effective Grading: A tool for learning and assessment. San Francisco: Jossey-Bass.

Lundin, M., Rensfeldt, A. B., Hillman, T., Andersson, A., \& Peterson, L. (2018). Higher education dominance and siloed knowledge: a systematic review of flipped classroom research. International Journal of Educational Technology in Higher Education, doi.org/10.1186/s41239-018-0101-6.

Shurair, M. N. (2017). Effectiveness of employing an educational environment based on the flipped classroom in developing grammar and students' attitudes towards it among grade 9 students in Gaza. Unpublished MA, Islamic University, Palestine.

Zainuddin, Z., \& Halili, S. H. (2016). Flipped Classroom Research and Trends from Different Fields of Study. International Review of Research in Open and Distributed Learning, 17(3), 313-340. doi.org/10.19173/irrodl.v17i3.2274

Zohi, N. (2014). What is Inverted Learning (Flipped Classroom)?. Retrieved on 20/1/2016, from: http://www.new-educ.com/outils-et-applications-de-la-classe-inversee. 


\section{An appendix \\ The studies included in the analysis}

1. Abanmi, Fahd bin Abdul Aziz. (1016). The Impact of using the flipped classroom strategy in teaching interpretation in achievement and the attitudes toward interpretation at second grade secondary students. Journal of Reading and Knowledge, Egypt, Issue (173), 21- 48.

2. Abd Elhalim, Safaa M. (2018). An Integrative Strategy Based on Incorporating Flipped Model of Instruction and Self Reflection Practices to Enhance EFL Students Listening Comprehension and Self-Regulated Learning. Studies in curricula and teaching methods, Egypt, (230), 50- 99.

3. Abdel Wahab, Mohamed Mahmoud. (2016). The Effectiveness of flipped E-learning strategy on E-books on the development of some reading comprehension skills among students in the Institute of Arabic Language Teaching for non-Arabic speakers at the Islamic University. Educational Magazine, Egypt, Issue (44), 637-672.

4. Abdul Ber, Abdul Nasser Mohamed Abdul Hamid. (2017). A proposed program based on inverted learning to develop the components of the mathematical structure and motivation towards learning among the female teacher students in the kindergarten stage. Journal of Mathematics Education, Egypt, 20(8), 6- 56.

5. Abdul Ghani, Karima Taha Noor. (2016). The Effectiveness of Flipped Learning Strategy to Develop The learning Achievement \& Learning Conservation of History at the Secondary School Students. Arab Studies in Education and Psychology, Saudi Arabia, Issue (74), 199-218.

6. Abdul Ghani, Karima Taha Nour. (2015). The Effectiveness of the Flipped Learning Strategy in Teaching History to Develop Communication Skills, Self-Learning, Improving Classroom Environment and Employing Modern Technology from the Point of View of a Sample of Secondary School Students and their Teachers. Educational and Social Studies, Egypt, 21(3), 367- 410.

7. Abdul Hakim, Mohammed Rajab. (2016). The Effectiveness of the Flipped Learning, Through the Blackboard System, in Developing Creative Teaching Skills and Reducing Teaching Anxiety Among Students of the Primary Education Program in the College of Education, University of Qatar. Journal of the Educational Society for Social Studies, Egypt, Issue (84), 59-111.

8. Abdul Hamid Hoyda Said. (2016). The Impact of the Interaction between Methods Navigate in the Flipped Learning Environment and the Level of Information Processing in the Motivation of Cognitive Development among Female Students from the Diploma Program Faculty of Education. Arab Studies in Education and Psychology, Saudi Arabia, Issue (73), 113- 153.

9. Abdul Latif, Sally Mohammed. (2016). The impact of using the flipped learning strategy on the development of the cognitive aspect and creative thinking skills in educations students teaching physical education lesson in the Faculty of Physical Education, Tanta University. Scientific Journal of Physical Education and Sports Sciences, Egypt, 5(77), 67-116.

10. Abdulaal, Mohamed Sayed. (2018). The Effectiveness of a Flipped Learning based ECourse Using Moodle System in Achieving Mathematics Teaching Course Objectives and Learning Satisfaction for Student Teachers at Faculty of Education. Journal of Mathematics Education, Egypt, 21(2), 43-95.

11. Abdullah, Lamia Galal. (2015). The effectiveness of the Flipped Classroom in the development of some of the mathematical concepts among educable mentally retarded students. Arab Studies in Education and Psychology, Saudi Arabia, (68), 439466.

12. Abdullah, Rehab Zanati. (2015). Based on Electronic Games, a Program to Overcome the Writing Difficulties Facing Non - Arabic Speaking Beginners Using the Virtual 
Inverted Classroom. Journal of the Faculty of Education, Al-Azhar University, Egypt, Issue (162), 251-314.

13. Abdul-Zaher, Amal Abu Al-Wafa. (2016). The Effectiveness of a Suggested Program based on Flipped Learning on Developing New Valley Faculty of Education First Year Mathematics Department Student Achievement Learning Attaining and Attitude Towards it. Journal of Mathematics Education, Egypt, 19(10), 161- 197.

14. Abu Alala Hala Said. (2015). Employment of Flipped learning model in teaching Home Economics and its Effect on dimensions of the Cognitive Load Among students of preparatory stage and their Attitudes towards it. Journal of the Faculty of Education, Alexandria, Egypt, 25(6), 459-518.

15. Abu Alraws, Adil Munir \& Amarah, Nuran Adil. (2016). The Effectiveness of Flipped Classroom in academic achievement and students' attitude in Faculty of Education at Qatar University. International Specialized Educational Journal, Jordan, 5(10), 276-249.

16. Abu Dunya, AbdelGawad Hassan. (2017). The Effectiveness of a typical different Activity practicing in flipped learning environment on developing the skills of producing bibliographic data lists for students of libraries, information and educational technology. Unpublished M.A. thesis, Al-Azhar University, Egypt.

17. Abu Jalbah, Muneerah shabeeb. (2015). The Effectiveness of Flipped Classroom Strategy by using Edmodo in the development of innovative Thinking creative, and students' attitude toward Biology among students of the first-grade secondary in Riyadh. Unpublished M.A. thesis, Imam Muhammad Bin Saud Islamic University, Saudi Arabia.

18. Abu Moghli, Heba Mohamed. (2017). The impact of the flipped learning strategy and the blended learning in developing reading comprehension and writing skills in the English language of primary stage students in Jordan. Unpublished $\mathrm{PhD}$ thesis, International Islamic Science University, Jordan.

19. Abu Ria, Hanan Hamdi. (2017). The Effect of the flipped classroom strategy in developing some genetics concepts and its associated problems solving skills in the first-grade secondary students. Journal of the Faculty of Education, Benha University, Egypt, 28(111), 216-258.

20. Adrian-Hollier, Lois Marie. (2015). Teaching with technology in the higher education classroom to affect student engagement and success: An action research study. Unpublished Ph.D. dissertation, Capella University, USA.

21. Ahmad, Iman Samir. (2018). Using the Flipped Classroom strategy for developing achievement, problems solving skills and reducing math anxiety towards the study of mechanics for the stage of secondary students. Journal of Mathematics Education, Egypt, 21(3), 260- 316.

22. Ahmed, Abdulaal Abdullah. (2016). The impact of the flipped learning strategy that is directed by the beyond-knowledge thinking skills in developing the skills needed to use interactive educational platforms for students of the Master of Education Technology. Educational and Social Studies, Egypt, 22(3), 1099- 1156.

23. Ahmed, Alaa Eddin Ahmed. (2018). The effectiveness of using flipped classroom in social studies to develop the skills of historical thinking among students in the middle school stage. Journal of Faculty of Education, Assiut University, 34(6), 518-557.

24. Akhoarsidah, Abeer Ahmad. (2017). The Effect of Using Flipped Classroom Strategy on Developing Mathematical Thinking and on Motivation towards Learning Mathematics among First Scientific Secondary Grade Students. Unpublished M.A. thesis, Faculty of Educational Sciences, Jordan.

25. Al - Hisnawi, Mowaffaq Abdul - Aziz \& Al - Waeli, Hussein Jarad. (2018). The effect of the using of the flipped e-learning to the development of students scientific thinking and motivation. International Journal of Educational and Psychological Sciences, Egypt, Issue (18), 12-32. 
26. Al - Subaie, Hessah Ghaida Fahd. (2017). The nature of computer teachers' attitudes toward using the flipped classroom strategy in Al-Kharj governorate of Al-Kharj in the light of some variables. Journal of Education, Al-Azhar University, Egypt, 1(173), 58-92.

27. Al Dhafeeri, Fayiz Mansher and Al-Mutairi, Fatemah Ayedh. (2018). Effectiveness of Flipped Classroom Model on Achieving the Levels of Bloom's Revised Taxonomy of the Cognitive Domain for Biology Course at the Eleventh Grade of Secondary Education. Message from the Arabian Gulf, Saudi Arabia, 39(149), 17-36.

28. AL Maagbeh, Ghaadeer Awad. (2015). The Effect of Using Flipped Learning on Ninth Graders' Achievement in English Grammar in Al-Qaser Directorate of Education. Unpublished M.A. thesis, Mutah University, Jordan.

29. Al-Ahmadi, Rasha Abdel-Karim and Brikit, Akram Mohammed. (2015). Efficacy of a Proposed Teaching Strategy Based on Blending Flip Classes and Authentic Assessment in Developing of grammatical skills among Female Students of SecondYear in Secondary School. Arab Studies in Education and Psychology, Egypt, Issue (58), 179-226.

30. Alatiyah, Nora Hamad. (2018). The effect of using the flipped classroom strategy in developing critical thinking skills among female students of the Faculty of Education, Majma University. Journal of Reading and Knowledge, Egypt, Issue (197), 17- 56.

31. Al-Bagaidi, Hissah Ghazi Barghash. (2018). Effective to Apply the Flipped Learning Via Blackboard System in Developing the Academic Achievement Going Towards the Flipped Learning for the Sixth Level of Kindergarten Department Students -Al Jouf University. Journal of the Islamic University for Educational and Psychological Studies, Palestine, 26(3), 29- 53.

32. AL-Balushya, Nawal Saif. (2014). The effectiveness of the flipped classroom strategy in teaching and investing in the Arabic language teaching. Third International Conference on Arabic Language, Dubai, United Arab Emirates, 7-10 / 5/2014 AD, Book 3, sponsored by the International Council of the Arabic Language.

33. AL-Baz, Marwa Mohammed. (2016). Effectiveness of flipped electronic course in developing science teaching skills for people with special needs and participatory learning skills among students and teachers at the Faculty of Education. Journal of Research in Education and Psychology, Minia University, Egypt, 29(1), 1-43.

34. Al-Darman, Haifa Mohamed Abdel Aziz. (2015). The impact of Flipped Classrooms strategies in the development of the academic achievement for students in sixth grade in Science Subject. Unpublished M.A. thesis, Faculty of the Arab East for Postgraduate Studies, Saudi Arabia.

35. Al-Dosari, Latifa Mohammed. (2017). The impact of teaching in a flipped classroom on the development of historical thinking skills among second grade students in the Kingdom of Bahrain. Journal of the Educational Association of Social Studies, Ain Shams University, Egypt, Issue (96), 215-244.

36. Al-Dossari Fuad Fahid and Al Massaad, Ahmed Zaid. (2017). The Effectiveness of Implementation Flipped Classroom Strategy on Academic Achievement to Learning Programming in a Computer Subject. International Journal for Research in Education, UAE University, 41(3), 137- 164.

37. Alduraibi, Uhood Saleh. (2016). Attitudes and perceptions of female university students about the application of Flipped Classroom in Higher Education. Arab Research Journal in the Field of Qualitative Education, Arab Education Association, Egypt, Issue (3), 253- 276.

38. Aleabiri, Ali Muhamad Atway. (2015). The effectiveness of the inverted teaching on the intermediate third grade students regarding curriculum of Figh and their attitude toward it. Unpublished M.A. thesis, Imam Muhammad Bin Saud Islamic University, Saudi Arabia. 
39. -Alebaikan, Reem a. \& Alhenaki, Mona s. (2016). The Effect of flippe d classroom teaching strategy on motivation towards learning in intermediate schools. International Specialized Educational Journal, Jordan, 5(8), 172- 186.

40. Alebrahim, Fatimah Hussain. (2016). Implementation evaluation study: Flipped classroom professional development with faculty members to enhance students' engagement in higher education. Unpublished Ph.D. dissertation, University of Northern Colorado, USA.

41. Alfahid, Mai Fahid. (2017). Disruptive Practice in Saudi EFL Student Teachers' Learning to Teach Through Flipped Classroom and Rehearsal: A Grounded Theory Study. Unpublished Ph.D. dissertation, The Pennsylvania State University, USA.

42. Al-Faleh, Maryam Abd al-Rahman. (2017). The Requirements of applying flipped classrooms strategy at Princess Nora University. Journal of Educational and Psychological Sciences, Palestine, 1(5), 57-73.

43. Al-Fayez, Mona Qatifan; Abu Al-Sheikh, Atiya Ismail; and Abu Atiya, Jawhara. (2017). The effect of using a flipped learning strategy in the development of academic achievement and creative thinking among Faculty of Princess Alia students of Balqa Applied University. Journal of the Faculty of Education in Educational Sciences, Egypt, 41(1), 123- 168.

44. Al-Fuhayd, May Fuhayd. (1435 H). The effectiveness of the flipped classroom strategy using mobile devices in developing attitudes towards the classroom environment and academic achievement in the English Grammar course for preparatory programs students at Imam Muhammad bin Saud Islamic University. Unpublished M.A. thesis. Imam Mohammed bin Saud Islamic University, Saudi Arabia.

45. Al-Ghamdi, Ibrahim Mohammed Ali. (2017). The Impact of using flipped learning strategy on Developing statistical thinking and statistical sense among graduate students. Journal of Mathematics Education, Egypt, 20(1), 97- 148.

46. Al-Hanan, Taher Mahmoud and Ahmad, Mohamed Saaduddin. (2016). The Effect of Using Flipped Learning Strategy in Teaching History on Developing Some SelfRegulated Learning Skills and Archaeological Awareness Among First Year Secondary Stage Students. Journal of the Educational Society of Social Studies, Egypt, Issue (79), 1- 78.

47. Alhaqilu, Walid Suleiman. (2016). The effect of using the Flipped Classroom strategy with video sharing in academic achievement in the Arabic language first grade. Unpublished M.A. thesis, Faculty of the Arab East for Postgraduate Studies, Saudi Arabia.

48. AL-Harbi, Fawzia Mutlaq. (2017). The effectiveness of the use of the Flipped Learning strategy in the development of self-learning skills and organizing the enrichment environment as perceived by gifted students. Journal of Special Education and Rehabilitation, Egypt, 4(16), 114- 152.

49. AL-Harthy, Meshary Hussein. (2018). The effect of flipped learning on the development of achievement and some mental habits of sixth graders in mathematics. Journal of the Faculty of Education in Port Said, Egypt, Issue (23), 371- 400.

50. AL-Hosaniah, Huda bint Ali. (2015). The Impact of Flipped Classroom in Developing Self-Efficacy and Achievement Among Grade 9 Students in the Sultanate of Oman. Unpublished M.A. thesis, Sultan Qaboos University, Sultanate of Oman.

51. Ali- Akram Fathi Mustafa. (2015). Developing an incentive design model for the flipped courses on its learning outcomes, level of information processing and acceptance of technology updates supporting people with special needs. Retrieved on: 5/8/2016, from: $h t t p / / w w w . k a u . e d u . s a$

52. Al-Jaribiah, Mona Mohammed. (2017). Effectiveness of using flipped classroom approach in teaching Course of Hadith upon learning progress of female students belonging to level four of secondary education (scientific) in Riyadh. Education, AlAzhar University, Egypt, 1(172), 703-762.

53. Al-Juhani, Manal Mohsen. (2017). The effectiveness of Flipped Classroom strategy in the development of mathematical representation and the attitude towards self- 
learning among second intermediate talented students in Jeddah. Journal of Mathematics Education, Egypt, 20(7), 6- 46.

54. Al-Kahili, Ibtisam Saud. (2015). Effectiveness of flipped classroom in education. Almadinat Almunwrat: Dar Alzaman.

55. AL-Kurd, Amal Ahmed (2017). Impact of Using Flipped Classrooms on Developing the Skill of Mathematical Problem Solving and Mathematical Communication among Female Ninth Graders in Gaza. Unpublished M.A. thesis, Islamic University, Gaza.

56. Al-Mashni, Yousef Ahmed Mohamed. (2016). The Effect of Flipped Learning on the seventh Grade Students' Achievement And their Creative Thinking in Science Subject. Unpublished M.A. thesis, Middle East University, Jordan.

57. Al-Montashari, Abdel-Karim Saleh. (2018). The Effect of using flipped learning strategy on achievement and skills performance of computer applications for intermediate stage students. Journal of Educational and Psychological Sciences, Egypt, Issue (11), 1- 100.

58. Al-Mu'adi, Abdulaziz bin Said bin Yahya. (2013). The Effectiveness of Applying Blended Learning in the Flipped Classrooms in the Developing Mathematical Thinking Skills for Fifth Graders. Unpublished M.A. thesis, Imam Mohammed bin Saud Islamic University, Saudi Arabia.

59. ALMuaither, Reem \& ALQahtany, Amal (2015). The Effectiveness of Flipped Classroom Strategy in the Development of the Information Security Concepts of the Female Students in the University Level. International Specialized Educational Journal, Jordan, 4(8), 21-39.

60. ALMuqati, Saleh Ibrahim. (2016). The Impact and Effectiveness of the Flipped Learning Strategy in the Academic Achievement of Students at the Fourth-Grade in (Introduction to Teaching) Course in the Faculty of Education at the University of Shaqra. International Specialized Educational Journal, Jordan, 5(8), 135- 158.

61. Al-Mutairi, Sarah Talaq Gali. (2015). Effectiveness of the flipped classroom strategy when using the Edmodo educational platform in developing self-learning skills and educational outcomes in the biology curriculum. Unpublished M.A. thesis, Imam Muhammad bin Saud Islamic University, Saudi Arabia.

62. Almwji, Suha Abdul Majeed, Zaki, Abdul Jawad and Makhlouf Lutfi (2018). Effectiveness of using Flipped Classroom in Developing Achievement and Numeracy Among Primary School Students. Journal of Mathematics Education, Egypt, 21(5), 291- 319.

63. AL-Najim, Mohammed Abdul Aziz. (2018). The Effect of flipped classroom strategy in Teaching Islamic culture on achievement and improving Islamic culture learning motivation among preparatory year students in Shaqra University. King Khalid University of Educational Sciences Journal, Saudi Arabia, 29(1), 347 320. The.

64. Alnashwan, Ahmed. (2017). The effectiveness of using Flipped Learning strategy in the teaching of the Arabic language on the development of reading comprehension skills and the survival of the impact of learning on sixth grade pupils in Riyadh. King Khalid University of Educational Sciences Journal, Saudi Arabia, Issue (28), 171-194.

65. AL-Omari, Radaan Salem. (2018). The Effectiveness of Flipped Classroom Strategy Among the Intermediate in Developing Academic Achievement in Fiqh Subject among High School Students. Journal of the College of Education, Assiut University, Egypt, 34(9), 42-65.

66. Al-Plassy, Rabab Abdel Maqsoud Youssef. (2015). The Impact of the Inverted Learning Strategy "Flipped Learning" in Developing the Skills needed for the Course "Electronic Operations" for the Learning Centers Management Diploma program students at Hail University. Educational and Social Studies, Egypt, 21(2), 121-146.

67. AL-Qarni, Fatima Mohammed. (2018). The impact of a training program done in a flipped learning environment in developing some of the e-training skills for 
educational supervisors in the Kingdom of Saudi Arabia. International Journal of Educational and Psychological Sciences, Egypt, Issue (14), 49-84.

68. Al-Rabian, Wafaa Mohammed Abdullah. (2017). The Effectiveness of Flipped Classroom by Using Easyclass Platform in Developing Critical Thinking Skills in Science for Intermediate Schoolgirls in Riyadh. International Specialized Educational Journal, Jordan, 6(2), 188- 201.

69. ALRougi, R. M.A. \& ALOtaibi, N. K. A. (2018). The Effectiveness of Using Flipped Classroom Strategy in Developing the Literary Appreciation Skills of First Grade Secondary Female Students. International Interdisciplinary Journal of Education, Jordan, 7(9), 1- 19.

70. AL-Ruwasa, Tahani Muhamad. (2018). The Academic Achievement and Mind Habits Development of The Student of Princess Norah bint Abdulrahman University. IUG Journal of Educational \& Psychological Studies, 26(1), 128-150.

71. AL-Sadoon, Elham. (2016). The Effect of flipped classroom on students' achievement and their satisfaction about the course. International Specialized Educational Journal, Jordan, 5(6), 1-11.

72. AL-Saudi, Rami Kamal al-Din. (2018). The interactive flipped learning model and its impact on the development of participatory learning skills and conceptual comprehension in science among middle school students. Unpublished M.A. thesis, University of Kafr ElSheikh, Egypt.

73. Alsayd, Sabah Abdulla Abdul Azim. (2014). The Use of Inverted Teaching in Developing Visual Thinking and Reducing Math Anxiety in Middle School with Hearing Disabilities' Students. Journal of Mathematics Education, Egypt, 17(6), 175- 234.

74. Al-Senaniyeh, Aisha Khamis and AL-Bulushiya, Rima Said. (2018). The Effectiveness of Flipped Classroom model on academic achievement in applied mathematics and attitudes toward mathematics among grade-eleventh female students in North Batinah Governorate Sultanate of Oman. Journal of Mathematics Education, Egypt, 21(7), 261- 304.

75. AL-Shami, Khadija Mahoder. (2018). The Effectiveness of Using the Flipped Learning Strategy to Acquire Physics Concepts Among Grade 9 Students and their Attitudes Toward Learning. Unpublished M.A. thesis, Al-Bayt University, Jordan.

76. Al-Shazly, Adel Ibrahim. (2018). The effectiveness of the flipped learning strategy in the development of some concepts of intellectual security among students in the middle school stage in the Egyptian track in Al-Ahsa governorate. Journal of Education, Al-Azhar University, Egypt, 2(177), 732-782.

77. Alshukeat, Huna Mustafaa Faris. (2016). The Effect of Using Blended Learning and Flipped Learning Strategies on the Achievement and Retention of Seventh Grade Students in Science Subject. Unpublished M.A. thesis, Middle East University, Jordan.

78. AL-Shummari, Muhammad Farhan \& Ali, Akram Fathi. (2017). The Effect of Different Content Organized in the Flipped Classroom on the Development of the Skills of the Presentations Design for Second Year Students in Intermediate School in Computer Curriculum. Journal of Arab Studies in Education \& Psychology, Issue (88), 77-108.

79. Alsiyd, Mahmoud Ramadan. (2018). The effectiveness of a proposed program using flipped learning to teach some of the new scientific topics in the acquisition of science graduates, scientific concepts, life skills development and pleasure learning. Egyptian Journal of Scientific Education, Egypt, 21(6), 121- 163.

80. Alsiyd, Yusra Mustafa. (2016). A proposed program according to the model of flipped learning to develop the concepts and skills of digital citizenship among students of the Education collrge and their attitudes towards the practice of ethics. Journal of the Arab Association for Educational Technology, Egypt, Issue (29), 105-229.

81. AL-Turki, Khalid Ibrahim \& Al-Subiei, Abdulaziz Nayef. (2016). The effectiveness of Flipped Classroom strategy in the developing critical thinking and environmental 
awareness in science among first year intermediate students at academic institutes. International Specialized Educational Journal, Jordan, 5(7), 166-185.

82. AL-Tweigy, Ahmed a. (2017). Effectiveness of the flipped learning strategy in the academic achievement of the critical thinking skills course of the students of the university of science and technology, Aden. International Specialized Educational Journal, Jordan, 6(9), 48-62.

83. Al-Zahrani, Abdul Rahman bin Mohammed. (2015). Effectiveness of the Flipped Classroom Strategy in Developing the Level of Cognitive Achievement of the ELearning Course Among the Students of the Faculty of Education, King Abdulaziz University. Journal of the Faculty of Education, Al-Azhar University. 162(1), 1-30.

84. Alziyn, Hanan (2015). The Effect of Using Flipped Learning Strategy on the Academic achievement of the Students in the Education Department in Princess Nourah bint Abdulrahman University. International Specialized Educational Journal, Jordan, 4(1), 171- 186, electronic version: www.iijoe.org/index.php/en/home/61the-i

85. Al-Zyoud, Samia Ahmad Salman. (2017). The Effect of a Flipped Classroom on Mathematics Achievement of Student in the Year 11 Scientific Stream and Attitude Toward it. Unpublished M.A. thesis, AL-Hashemite University, Jordan.

86. Ammar, Hanan Mohammed Saleh. (2015). The Effect of Using Flipped Classroom Strategy Across the Content Management System " Acadox" to Increase Cognitive Achievement and Performance Skills in the Computer System Course for the Technology Education Students. Arab Studies in Education and Psychology, Saudi Arabia, Issue (68), 17-76.

87. Atkins, Katrina. (2018). Student Perceptions and Student Achievement in a Higher Education Partially Flipped Classroom. Unpublished Ph.D. dissertation, Liberty University, USA.

88. Awidi, Isaiah T. \& Paynter, Mark. (2019). The impact of a flipped classroom approach on student learning experience. Computers \& Education, 128, 269- 283.

89. Bayoumi, Yasser Abdel Rahim \& Aljundi, Hassan Awad. (2016). The Effectiveness of flipped classroom strategy on Achievement of the fourth-grade pupils and to keep their learning effect and attitudes towards it. Journal of the Faculty of Education, Tanta University, Egypt, 64(4), 1- 57.

90. Bergstresser, Melody B. (2018). Teaching Students with Dyslexia Using the Flipped Classroom Method. Unpublished Ph.D. dissertation, Northcentral University, USA.

91. Bilal, Amani Abdel Moneim. (2018). The impact of the flipped classroom teaching strategy on the development of grammatical concepts and educational achievement among primary school students. Journal of Reading and Knowledge, Egypt, Issue (203), 15- 43.

92. Bishop, Jacob L. (2013). A controlled study of the flipped classroom with numerical methods for engineers. Unpublished Ph.D. dissertation, Utah State University, USA.

93. Bishop, Jacob Lowell and Verleger, Mathew A. (2013). The flipped classroom: A survey of the research. Paper presented at the 120th ASEE annual conference and exposition, American Society for Engineering Education.

94. Bormann, J. (2014). Affordances of Flipped Learning and its Effects on Student Engagement and Achievement. Unpublished M.A. thesis, University of Northern IOWA.

95. Brogdon, Laura Christine. (2018). Implementation of the Flipped Classroom: How is the In-Class Time Used?. Unpublished Ph.D. dissertation, University of Kansas, USA.

96. Brown, Anna F. (2012). A phenomenological study of undergraduate instructors using the inverted or flipped classroom model. Unpublished Ph.D. dissertation, Pepperdine University, USA. 
97. BROWN, K. C. (2015). Evaluating student performance and perceptions in a flipped introductory undergraduate biology classroom. Unpublished M.A. thesis, University of Massachusetts Boston

98. Butzler, Kelly B. (2015). ConfChem Conference on Flipped Classroom: Flipping at an Open-Enrollment College. Journal of Chemical Education, Easton, 92(9), 1574- 1585.

99. Carlisle, Christin S. (2018). How the Flipped Classroom Impacts Students' Math Achievement. Unpublished Ph.D. dissertation, Trevecca Nazarene University, USA.

100.Cashin, Marisa. (2016). The Effect of Flipped Classrooms on Elementary Students' Reading Scores. Unpublished Ph.D. dissertation, Northcentral University, USA.

101.Caverly, Gregg. (2017). A Technology Leader's Role in Initiating a Flipped Classroom in a High School Math Class. Unpublished Ph.D. dissertation, New Jersey City University, USA.

102.Clark, K. R. (2013). Examining the Effects of the Flipped Model of Instruction on Student Engagement and Performance in the Secondary Mathematics Classroom: AN Action Research Study. Unpublished Ph.D. dissertation, Capella University.

103.Collins, Michael A. (2015). Examining the perspectives of teachers and school building leaders on the use of the flipped classroom method in New York City public schools. Unpublished Ph.D. dissertation, Sage Graduate School, USA.

104.Coufal, K. (2014). Flipped learning instructional model: perceptions of video delivery to support engagement in eighth grade math. Unpublished Ph.D. dissertation. Lamar University.

105.Cunnings, Christopher P. (2016). Assessing the development $\mathcal{E}$ implementation of a student-centered, "flipped" secondary physics curriculum in which IO-lab digital sensors are issued to students on a 1-to-1 basis. Unpublished Ph.D. dissertation, University of Illinois at Urbana-Champaign, USA.

106.Dafoe, Kendra R. (2016). Caring in a Flipped Mathematics Classroom. Unpublished Ph.D. dissertation, The University of Toledo, USA.

107.Dehghanzadeh, S. \& Jafaraghaee, F. (2018). Comparing the effects of traditional lecture and flipped classroom on nursing students' critical thinking disposition: A quasi-experimental study. Nurse Education Today, 71, 151-156.

108.Dixon, Keshia L. (2017). The effect of the flipped classroom on urban high school students' motivation and academic achievement in a high school science course. Unpublished Ph.D. dissertation, Liberty University, USA.

109.Dokhi, Fawzi Abdul Latif. (2017). The Effectiveness of the Flipped Learning Strategy on increasing the academic achievement of the integrated learning disabilities students and reducing the number of hours they spend in the resource rooms. Journal of Faculty of Education - Tanta University, Egypt, 65(1), 214-254.

110.Dombrowski, T.; Wrobel, C.; Dazert, S. \& Volkenstein, S. (2018). Flipped classroom frameworks improve efficacy in undergraduate practical courses a quasi-randomized pilot study in otorhinolaryngology. National Center for Biotechnology Information, U.S. National Library of Medicine,

111.Dong, Anmei. (2018). Understanding of Students' Learning Engagement in the Flipped Classroom. Unpublished Ph.D. dissertation, The Chinese University of Hong Kong, Hong Kong.

112.Duffy, Colleen M. (2016). The impact of flipped learning on student achievement in an eighth-grade earth science classroom. Unpublished Ph.D. dissertation, Wilkes University, USA.

113.Durak, Hatice Yildiz. (2018). Flipped learning readiness in teaching programming in middle schools: Modelling its relation to various variables. Wiley Journal of Computer Assisted Learning, 34, 939- 959

114.Eid, Samah Mohammed. (2017). The Effectiveness of the Flipped Classroom Strategy in Teaching Science Teaching Methods Course for Developing the Academic 
Achievement and the Attitudes Toward Science Teaching Among Female Student Teachers. Journal of Faculty of Education, Assiut, Egypt, 33(8), 267-334.

115.El Shamy, Enas Abed El Moez. (2017). Effect of Flipped Electronic Course on the Teaching Performance and Reflective Thinking Skills of the Teacher Female Students at the Faculty of Home Economics, Al-Azhar University. Arab Studies in Education and Psychology, Egypt, vol. 5, 1157-1141.

116.El-Aahwal, Ahmed Said Mahmoud. (2016). The Effectiveness of Using the InvertedLearning Strategy in Developing the Grammatical Skills and Trend towards the syllabus Among High-School Students. Education and Psychology letter, Saudi Arabia, Issue (55), 41-67.

117.Elakovich, Denise Marie. (2018). Does a Student's Use of Selfregulation Change in the Flipped Classroom?. Unpublished Ph.D. dissertation, Montana State University, USA.

118.Elyyan, Ayman Y. \& Abed, Osama H. (2017). The Effect of Using the Flipped Classroom Strategy in Teaching Arabic language on the Achievement of University Students in Qatar State and their Attitudes Towards it. Letter from the Arabian Gulf, Saudi Arabia, Issue (145), 69-84.

119.Farhoud, Mona Abdel Monem. (2015). The effect of merging Tools for open educational courses in a flipping learning environment to develop the skills of producing educational video for Students in computer teacher Preparation Department. Journal of Arab Studies in Education and Psychology (ASEP), Egypt, 2(61), $57-110$.

120.Ghaith, Tariq Abdul Wadood; Khamis, Mohammed Attia; \& Salami, Zainab Hassan. (2017). The Effect of two video footage patterns presented in the Flipped classroom model on developing attention among secondary stage students, industrial education. Journal of Scientific Research in Education, Egypt, 11(18), 185-214.

121.Ghareeb, Ahmed Mahmoud. (2017). Video visualizations with the flipped learning strategy and its impact on the development of the scientific documentation skills in diploma students of Graduate Studies College for Education. Education Technology Studies and Research, Egypt, Issue (32), 41-92.

122.Girmen, Pinar \& Kaya, Mehmet Fatih. (2019). Using the Flipped Classroom Model in the Development of Basic Language Skills and Enriching Activities: Digital Stories and Games. International Journal of Instruction, 12(1), 555-572.

123.Gopalan, Chaya (2019). Effect of flipped teaching on student performance and perceptions in an Introductory Physiology course. Advances in Physiology Education, 43(1), 28- 33.

124.Gouda, Samia Hussein. (2018). Using Flipped Classroom in the Teaching Discrete mathematics for Developing some Divergent Thinking Skills and Levels of Information Processing among Mathematics Department Students at Tabuk University. Educational Magazine, Kuwait, 32(127), 279- 330.

125.Gough, Evan. (2016). Southwest and South-Central Minnesota K-12 teachers' perceptions regarding the flipped classroom. Unpublished Ph.D. dissertation, University of South Dakota, USA.

126.Gough, Evan. (2016). Southwest and South-Central Minnesota K-12 teachers' perceptions regarding the flipped classroom. Unpublished Ph.D. dissertation, University of South Dakota, USA.

127.Grabau, Christopher R. (2015). Undergraduate student motivation and academic performance in a flipped classroom learning environment. Unpublished Ph.D. dissertation, Saint Louis University, USA.

128. Granero Lucchetti, Alessandra Lamas; Ezequiel, Oscarina da Silva; Oliveira, Isabella Noceli de; Moreira-Almeida, Alexander \& Lucchetti, Giancarlo. (2018). Using traditional or flipped classrooms to teach "Geriatrics and Gerontology"? 
Investigating the impact of active learning on medical students' competences. Medical teacher, 40(12), 1248-1256.

129.Greene, Michael Alan. (2018). Factors That Influence Student Performance in Physics. Unpublished Ph.D. dissertation, The University of Texas at Arlington, USA.

130.Griffey, James Derrick. (2017). Flipping the Classroom in Community Colleges: Rethinking History Instruction to Develop Workforce Desirable Skills. Unpublished Ph.D. dissertation, The University of Alabama, USA.

131.Gross, Anna Lynn. (2014). The flipped classroom: Shakespeare in the English classroom. Unpublished M.A. dissertation, North Dakota State University, USA.

132.Guggisberg, Larry S. (2015). Student perceptions of digital resources and digital technology in a flipped classroom. Unpublished Ph.D. dissertation, The University of North Dakota, USA.

133. Hamdallah, Amal Fayez. (2016). The Impact of Using Flipped Learning Strategy in Developing Inductive Thinking Among Grade 8 Students in the Arabic Grammar Course. Unpublished M.A. thesis, Middle East University, Jordan.

134. Hamza, Ihab Mohamed Abdel Azim. (2015). The influence of the two integrated teaching patterns (flexible / inverted) in providing education students some audio producing skills. Educational and Social Studies, Egypt, 21(4), 49-106.

135. Hantla, Bryce F. (2014). The Effects of flipping the classroom on specific aspects of critical thinking in a Christian college: a quasi-experimental, mixed methods study. Unpublished Ph.D. dissertation, Southeastern Baptist Theological Seminary, USA.

136.Hantla, Bryce F. (2014). The effects of flipping the classroom on specific aspects of critical thinking in a Christian college: A quasi-experimental, mixed-methods study. Unpublished Ph.D. dissertation, Southeastern Baptist Theological Seminary, USA.

137.Harb, Sulayman Ahmad. (2018). The Effectiveness of two Types of Flipped Learning with Digital Video: (normal and interactive) in Developing the Skills of Designing and Producing the Educational Video among the Female Students at Al-Aqsa University of Gaza. Palestinian Journal of Open Education, Palestine, 6(12), 65-78

138.Harun, Tayeb Ahmed \& Sarhan, Mohamed Omar. (2015). The Effusiveness of flipped learning model on achievement and skills performance in E-Learning for undergraduate students at faculty of education. The First International Conference of the College of Education "Education - Future Prospects", King Abdulaziz Civilization Center for, 12-15 / 4/2015, University of Baha, Saudi Arabia.

139.Hassan, Nabil El Sayed Mohamed. (2015). The Effectiveness of Flipped Learning Based on Video Podcasting in Developing Electronic Tests Design Skills Among Staff Members at Om-ElKoura University. Arab Studies in Education and Psychology, Saudi Arabia, Issue (61), 113- 176.

140.Hawass, Najla Youssef. (2015). Effectiveness of using the flipped classroom strategy in developing classroom interaction skills to teach Arabic grammar for second grade students. Arab Studies in Education and Psychology, Saudi Arabia, (62), 249-277.

141.Heredia, Kristin. (2015). The Effects of the Flipped Classroom Model on Student Academic Growth in Flipped and Traditional Community College Classrooms. Unpublished Ph.D. dissertation, Aurora University, USA.

142.Herreid, Clyde. F., \& Schiller, N. A. (2013). Case studies and the flipped classroom. Journal of College Science Teaching, National Science Teachers Association, 42(5), 62-66.

143.Hojnacki, Susan G. (2018). The Flipped Classroom in Introductory Foreign Language Learning. Unpublished Ph.D. dissertation, Michigan State University, USA.

144.Holik, Michael T. (2016). Comparing the Effectiveness of Flipped Classroom and Traditional Classroom Student Engagement and Teaching Methodologies. Unpublished Ph.D. dissertation, Lindenwood University, USA.

145. Howell, Donna. (2013). Effects of an Inverted Instructional Delivery Model on Achievement of Ninth-Grade Physical Science Honors Students. Unpublished Ph.D. dissertation, Gardner-Webb University, USA. 
146.https://www.ncbi.nlm.nih.gov/pmc/articles/PMC6280380/pdf/12909_2018_Article_1398.pdf

147.Huereca, Karla. (2015). High school mathematics teachers' connective knowledge of the challenges and possibilities in implementing the flipped learning model: an embedded mixedmethods study. Unpublished Ph.D. dissertation, The University of Texas at El Paso, USA.

148.Huereca, Karla. (2015). High school mathematics teachers' connective knowledge of the challenges and possibilities in implementing the flipped learning model: an embedded mixedmethods study. Unpublished Ph.D. dissertation, The University of Texas at El Paso, USA.

149.Humaid, Amal Khalid Mohammed. (2016). The effectiveness of the Flipped and Blended Classroom in developing the skills of educational website's design amongst the female students in the Faculty of Education at the Islamic University of Gaza. Unpublished M.A. thesis, Islamic University of Gaza, Palestine.

150.Hunley, Rebecca C. (2016). Teacher and Student Perceptions on High School Science Flipped Classrooms: Educational Breakthrough or Media Hype? Unpublished Ph.D. dissertation, East Tennessee State University, USA.

151.Ibrahim, Asim Mohammed. (2017). The effectiveness of teaching general science course using the flipped classroom strategy in the developing cognitive achievement and the scientific added value among Faculty of Education students. Journal of Educational and Psychological Sciences, Bahrain, 18(4), 423- 471.

152.Ibrahim, Bassam Abdullah and Ahmad, Amani Yahya. (2017). The Effect of Teaching Science Using Flipped Classroom Strategy on Developing Science Processing and Problem Solving Among the Faculty of Educational Sciences Students in Jordan. Journal of the Association of Arab Universities for Higher Education Research, Damascus, 37 (1), 55-82.

153.INAN, Nihan Kutahnecioglu; Balakrishnan, Kavitha \& Refeque, Muhammed. (2019). Flipping perceptions, engagements and realities: A case study. Turkish Online Journal of Distance Education (TOJDE), 20(1), 208-222.

154.Ismail, Abdul Raouf Mohammed. (2017). The effect of the interaction between the two method of controlling (progressive / retrograde) of the flipped learning in developing the interaction skills, electronic sharing and the adjustment of the achievement responsibility attitudes among students of high and low motivation. Education Technology Studies and Research, Egypt, Issue (31), 139-252.

155.Ismail, Reda Al Sayed. (2018). A proposed program for the 'Teaching student' in the class of Geography, College of Education, using the flipped classroom and social networking sites for the development of teaching skills and social interaction and its impact on the development of geographical thinking skills for people with visual disabilities. Journal of the Educational Society of Social Studies, Ain Shams University, Egypt, Issue (99), 1 - 91.

156.Ismeel, Marwa Hussein. (2015). The Effectiveness of the Reversed Learning Strategy in Teaching Geography to Develop the Skills of Geographical Research Among High School Students. Journal of the Educational Association for Social Studies, Ain Shams University, Egypt, Issue (75), 173-218.

157.Ismeel, Wiam Mohamed El Sayed. (2017). Evaluation of Flipped Learning Model from the Viewpoint of Female Students at Najran University. Educational Magazine, Saudi Arabia, Issue (48), 217-251.

158.Jad Allah, Ziad Ahmad. (2014). The Impact of Two Styles Strategy for Flipped Learning on the Achievement and Motivation of Primary Stage Students in Science Learning. Unpublished M.A. thesis, International Islamic University, Jordan.

159.Jerawi, Siham Salman. (2016). A comparative study of students' learning methods preferences from their point of view. Journal of Education, Al-Azhar University, Egypt, 1(169), 502- 529. 
160.Kenna, Donald Christian. (2014). A study of the effect the flipped classroom model on student self-efficacy. Unpublished M.A. dissertation, North Dakota State University, USA.

161.Keshta, Aya Khalil Ibrahim. (2016). The Impact of Using the Flipped Learning Strategy on Concept Development and Reflective Thinking in Biology among Female Tenth Graders. Unpublished M.A. thesis, Islamic University, Palestine.

162.Khalaf, Mohamed Hassan Ragab. (2016). The Effect of The Two Flipped Learning Styles (Peer Instruction / Inquiry) on Developing the Using Skills of Social Software in Instruction \& Increasing the Achievement Motivation of the General Diploma Students in The Faculty of Education Alexandria University. Arab Studies in Education and Psychology, Saudi Arabia, Issue (72), 15-89.

163.Khalifa, Zainab Mohamed Hassan. (2016). The Impact of Interaction Between the Timing of Providing Guidance \& Cognitive Style in Flipped Learning Environment on the improvement of Electronic Courses production skills for Members of the Assistant Teaching Staff. Arab Studies in Education and Psychology, Saudi Arabia, Issue (77), 67- 138.

164.Khalil, Ibrahim bin al-Hussein. (2015). The Effect of the using flipped classroom strategy on some components of the self-organized learning and the trend towards mathematics. $\quad$ Retrieved on 15/8/2016 from https://www.researchgate.net/publication/304270120

165.Khreis, Ala Mohammed Dheeb. (2017). The Effect of Flipped Learning Strategy on Developing Critical Skills of Tenth Basic Grade Students in Islamic Education in Jordan. Unpublished M.A. thesis, Yarmouk University, Jordan.

166.Kim, Minsun; Roh, Sangho \& Ihm, Jungjoon. (2018). The relationship between noncognitive student attributes and academic achievements in a flipped learning classroom of a pre-dental science course. Korean Journal of Medical Education, 30(4), 339-346.

167.Kinderman, Kelly A. (2015). The flipped classroom: An alternative to teaching models in an elementary classroom. Unpublished M.A. dissertation, The University of the Arts, USA.

168.Ksoy, Gulsum. (2018). The effects of the gamified flipped classroom environment (GFCE) on students' motivation, learning achievements and perception in a physics course. Quality \& Quantity, 52(1), 129-145.

169.Largo, Kerri J. (2017). The Flipped Learning Model: Teachers' Perceptions and Usage in Secondary Education. Unpublished Ph.D. dissertation, Illinois State University, USA.

170.Larsen, A. Judy. (2013). Experiencing a Flipped Mathematics Class. Unpublished M.A. thesis, Simon Fraser University, Canada.

171.Li, Sainan. (2016). A Study of Learners' Satisfaction towards College Oral English Flipped Classroom. Theory and Practice in Language Studies, London, 6 (10), 1958-1963.

172.Link, Philip. (2016). Teacher Readiness for Implementation of Daily Flipped Classroom Technology Instruction. Unpublished Ph.D. dissertation, Southwest Baptist University, USA.

173.Long, Taotao; Cummins, John; Waugh, Michael. (2017). Use of the flipped classroom instructional model in higher education: instructors' perspectives. Journal of Computing in Higher Education, Dordrecht, 29(2), 179-200.

174.Lubna, Awatif Abdelaziz. (2017). An applied model for teaching family education courses using the flipped classroom strategy to develop life practical skills. Egyptian Journal of Specialized Studies, Egypt, Issue (17), 14- 58. 
175.Lundin, Mona; Rensfeldt, Annika Bergviken; Hillman, Thomas; Lantz-Andersson, Annika; Peterson, Louise. (2018). Higher education dominance and siloed knowledge: a systematic review of flipped classroom research. International Journal of Educational Technology in Higher Education, Heidelberg, 15, 1-30.

176.Mahmoud, Ghada Omar. (2018). The effect of using the flipped learning method on improving teaching skills of the 'teaching student' in the course of Swordplay. Assiut Journal of Physical Education Sciences and Arts, Egypt, 1(47), 109-125.

177.Martin, Amanda Grace. (2015). The impact of flipped instruction on middle school mathematics achievement. Unpublished Ph.D. dissertation, Texas A\&M University, USA.

178.McNally, Brenton; Chipperfield, Janine; Dorsett, Pat; Fabbro, Letitia Del; Frommolt, Valda; Goetz, Sandra; Lewohl, Joanne; Molineux, Matthew; Pearson, Andrew; Reddan, Gregory; Roiko, Anne \& Rung, Andrea. (2016). Flipped classroom experiences: student preferences and flip strategy in a higher education context. Springer Science+Business Media Dordrecht, High Educ, 73, 281-298.

179.Mehring, J. G. (2015). AN Exploratory study of the lived experiences of japanese undergraduate efl students in the flipped classroom. Unpublished Ph.D. dissertation. Pepperdine University.

180.Merrill, Julie Elaine. (2015). The flipped classroom: An examination of veteran teacher' practices when flipping their classrooms for the first time. Unpublished Ph.D. dissertation, Texas A\&M University, USA.

181.Missildine, Kathy; Fountain, Rebecca; Summers, Lynn \& Gosselin, Kevin. (2013). Flipping the Classroom to Improve Student Performance and Satisfaction. Journal of Nursing Education, 52 (10), 597-599.

182. Mohammed, Iman Zaki. (2016). The interactive effect between the activities pattern and the learning style of the flipped classroom environment on the development of academic achievement, academic self-efficacy and educational satisfaction among students of educational technology. Arab Association for Educational Technology, Egypt, Issue (29), 232-326.

183.Moran, Clarice Makemson. (2014). Changing Paradigms: A Mixed Methods Study of Flipping the English Language Arts Classroom. Unpublished Ph.D. dissertation, North Carolina State University, USA.

184.Narendran, Roshni. (2018). The role of self-determination theory in developing curriculum for flipped classroom learning: A Case Study of First-Year Business Undergraduate Course. Journal of University Teaching \& Learning Practice, 15(5), 14499789.

185.Nazar, Hamde; Omera, Usmaan; Nazarb, Zachariah \& Husband, Andy. (2018). A study to investigate the impact of a blended learning teaching approach to teach pharmacy law. International Journal of Pharmacy Practice, https://onlinelibrary.wiley.com/doi/abs/10.1111/ijpp.12503

186.Ogden, Lori. (2014). Flipping the Classroom in College Algebra: A Design and Development Study. Unpublished Ph.D. dissertation, West Virginia University, USA.

187. Osman, Heba Abdul Hafeez. (2016). The Effect of Using Flipped Learning Strategy on the Achievement of Seventh Grade Female Students in Science and Their Attitudes towards Science. Unpublished M.A. thesis, Yarmouk University, Jordan.

188. Othman, Ilham Galal \& Hassan, Rola Naim. (2017). The effectiveness of a training program to develop the knowledge and attitudes of middle and secondary stage teachers towards using the flipped learning strategy. World of Education, Egypt, Issue (57), 1-63.

189. Overmyer, Gerald Robert. (2014). The flipped classroom model for college algebra: Effects on student achievement. Unpublished Ph.D. dissertation, Colorado State University, USA. 
190.Prefume, Yuko Enomoto. (2015). Exploring a Flipped Classroom Approach in a Japanese Language Classroom: A Mixed Methods Study. Unpublished Ph.D. dissertation, Baylor University, USA.

191.Quint, C. L. (2015). A Study of the efficacy of the flipped classroom model in a university mathematics class. Unpublished Ph.D. dissertation. Columbia University.

192.Rakha, Iman Ahmed; Dessouki, Mohamed Ibrahim; Zine El Din, Mohamed Mahmoud; \& Farhoud, Mona Abdel Moneim. (2017). Proposed model for the employment of open educational courses Tools based on the development of flipped learning skills of college student's quality education. Journal of Faculty of Education, Port Said University, Egypt, Issue (22), 369-385.

193.Ramaglia, Heather. (2015). The flipped mathematics classroom: A mixed methods study examining achievement, active learning, and perception. Unpublished Ph.D. dissertation, Kansas State University, USA.

194.Rashid, Tahira Sidqi. (2017). The effectiveness of a science program applying the flipped classroom in developing educational outcomes, creative problem solving skills and motivation in gifted students with learning difficulties in the primary fourth grade. Educational Sciences, Egypt, 25(2), 152- 196.

195.Reinhardt, Jill Y. (2014). Improving classroom practice through collaborative inquiry: A case of flipped learning. Unpublished Ph.D. dissertation, The University of North Carolina at Greensboro, USA.

196.Renfro, Allen. (2014). Assessing the effects of a flipped classroom approach on student achievement, mathematical thinking, attitudes, and teacher perceptions in an undergraduate calculus class using a participatory action research approach. Unpublished Ph.D. dissertation, Robert Morris University, USA.

197.Rifai, Ahmed Mohamed. (2016). Use a strategy based on Flipped Classroom to improve achievement of functions, reduce misconceptions and attitude towards instruction for the students of administrative science path. Journal of Mathematics Education, Egypt, 19(1), 184-220.

198.Ripley, Darren G. (2015). An Examination of Flipped Instructional Method on Sixth Graders' Mathematics Learning: Utilizing Propensity Score Matching. Unpublished Ph.D. dissertation, University of Nevada, USA.

199.Sahin A., Cavlazoglu, B., \& Zeytuncu, Y. E. (2015). Flipping a College Calculus Course: A Case Study. Educational Technology \& Society, 18 (3), 142-152.

200.Saif, Nayel Yousef \& Najdi, Samir Mousa. (2018). The effectiveness of using the flipped classroom strategy on developing grammatical concepts included in the language skills course for the Foundation students at Tabuk University. Journal of Scientific Research in Education, Egypt, 8(1), 199-223.

201.Salah, Wasam Isbiatan. (2017). The Effectiveness of Using Flipped Classroom Based on Virtual Labs in Developing the Skills of Designing and Programming Arduino among Technology 11th Graders in Gaza. Unpublished M.A. thesis, Islamic University, Palestine.

202.Salinas, Amanda Jane. (2017). Differences in the Critical Thinking Between Accounting Students in Flipped and Traditional Classes. Unpublished Ph.D. dissertation, Northcentral University, USA.

203.Samra, Emad Mohamed. (2016). The impact of the learning strategies (electronic/ flipped) on the development of cognitive outcomes and self-efficacy among a sample of students in the Department of Information Science, Faculty of Social Sciences Umm Al-Qura. Arab Association for Educational Technology, Egypt, Issue (28), 45- 109.

204.Saunders, JoRanna Marita. (2014). The flipped classroom: Its effect on student academic achievement and critical thinking skills in high school mathematics. Unpublished Ph.D. dissertation, Liberty University, USA. 
205.Schwankl, E. (2013). Blended Learning; Achievement and Perception Flipped Classroom; Effects on Achievement and Student Perception. Unpublished Ph.D. dissertation, Southwest Minnesota State University.

206.Shalabi, Ilham. (2016). The Effectiveness of Using Flipped Classroom Strategy Program in the Development of Evaluation Competencies and Habits of Mind for the Student-Teacher in Imam Muhammad Ibn Saud Islamic University. Studies in Curriculum and Teaching Methods, Egypt, Issue (214), 131- 187.

207.Sharpe, Erin Humphrey. (2016). An investigation of the flipped classroom in algebra two with trigonometry classes. Unpublished Ph.D. dissertation, Regent University, USA.

208.Shoman, Ghada Shoman. (2018). The Effectiveness of a program based on flipped learning using learning management system on developing teaching performance and attitude towards internet-based learning for pre-service math teachers of elementary stage. Journal of Mathematics Education, Egypt, 21(7), 197- 260.

209.Shurair, maysar Nasser. (2017). Effectiveness of employing an educational environment based on the flipped classroom in developing grammar and students' attitudes towards it among grade 9 students in Gaza. Unpublished M.A. thesis, Islamic University, Palestine.

210.Sierra, H. (2015). Students' Experiences in a Math Analysis Flipped Classroom. Unpublished M.A. thesis, Chapman University, Orange, California.

211.Smallhorn, Masha. (2017). The flipped classroom: A learning model to increase student engagement not academic achievement. Student Success, Brisbane, 8(2), 4353.

212.Smith, Jay P. (2015). The efficacy of a flipped learning classroom. Unpublished Ph.D. dissertation, McKendree University, Lebanon.

213.Smith, Jay P. (2015). The efficacy of a flipped learning classroom. Unpublished Ph.D. dissertation, McKendree University, USA.

214.Snowden, K. (2012). Teacher perceptions of the flipped classroom; Using video lectures online to replace traditional in-class lectures. Unpublished M.A. thesis, University of North Texas.

215.Subramaniam, Suwarna Rani \& Muniandy, Balakrishnan. (2017). The Effect of Flipped Classroom on Students' Engagement. Springer Science+Business Media, Tech Know Learn, https:/ / doi.org/10.1007/s10758-017-9343-y

216.Suleiman, Ali Mohammed. (2017). Flipped classroom Strategy and Development of Teaching Skills and Professional Self-Esteem for the 'Teaching Students': An Empirical Study. Journal of Education, Al-Azhar University, Egypt, 2(176), 12-73.

217.Sun, Zhiru. (2015). The Role of Self-Regulation on Students' Learning in an Undergraduate Flipped Math Class. Unpublished Ph.D. dissertation, The Ohio State University, USA.

218.Sun, Jerry Chih-Yuan \& Wu, Yu-Ting. (2016). Analysis of Learning Achievement and Teacher-Student Interactions in Flipped and Conventional Classrooms. International Review of Research in Open and Distance Learning, suppl. Special Issue: Research Papers in Online Learning, Athabasca, 17 (1), 79 - 99.

219.Tarazi, Nadine. (2016). The Influence of the Inverted Classroom on Student Achievement and Motivation for Learning in Secondary Mathematics in the United Arab Emirates: A Quasi-Experimental Study. Unpublished Ph.D. dissertation, Northcentral University, USA.

220.Torkelson, V. (2012). The Flipped classroom, putting learning back into the hands of students. Unpublished M.A. thesis, Saint Mary's College of California.

221.Wells-Beede, Elizabeth. (2018). The Flipped Classroom in Nursing Education as Described by the Nurse Educators Experience. Unpublished Ph.D. dissertation, Capella University, USA.

222.Wenzler, Heather Rebecca. (2017). The Flipped Classroom Model and Academic Achievement: A Pre and Posttest Comparison. Unpublished Ph.D. dissertation, Northcentral University, USA. 
223.Wiginton, B. (2013). Flipped instruction; An investigation into the effect of learning environment on student self-efficacy, learning style and academic achievement in Algebra 1 classroom. Unpublished Ph.D. dissertation, The University of Alabama.

224.Wiley, B. M. (2015). The Impact of the Flipped Classroom Model of Instruction on Fifth Grade Mathematics Students. Unpublished Ph.D. dissertation. University of Minnesota.

225.Winter, Joshua W. (2016). Flipped learning in a middle school classroom: analysis of the individual and group learning spaces. Unpublished Ph.D. dissertation, University of Hawai'i at Manoa, USA.

226.Xiao, N. Thor; Zheng, M.; Baek, J. \& Kim, G. (2018). Flipped classroom narrows the performance gap between low and high performing dental students in physiology. Advances In Physiology Education, American Physiological Society, 42(4), 586-592.

227.Yemma, Danielle M. (2015). Impacting learning for $21^{\text {st }}$ century students: A phenomenological study of higher education faculty utilizing a flipped learning approach. Unpublished Ph.D. dissertation, Robert Morris University, USA.

228.Yu, Daniel. (2016). An Exploratory Study on Flipped Learning and the Use of SelfRegulation Amongst Undergraduate Engineering Students. Unpublished Ph.D. dissertation, University of Southern California, USA.

229.Zaghloul, Nadia Hassan. (2017). The Effectiveness of the flipped classroom strategy in the level of learning some basic skills in gymnastics for students in the fifth grade of basic education in the UAE. Assiut Journal of Physical Education Sciences and Arts, Egypt, 3(44), 290- 317.

230.Zahid, Manal Abdullah. (2016). The Effectiveness of Reflective Learning strategy using Blackboard system and What's up application on Academic achievement and the trend towards the use of the Internet in the education of students' Home Economics Department, Faculty of Education, Prince Sultan bin Abdul-Aziz University. The Arab Journal for Science and the publication of Research, Palestine, 2(8), 35- 53.

231.Zainuddin, Zamzami \& Perera, Corinne Jacqueline. (2019). Exploring students' competence, autonomy and relatedness in the flipped classroom pedagogical model. Journal of Further and Higher Education, 43(1), 115-126.

232.Zainuddin, Zamzami; Halili, Siti Hajar. (2016). Flipped Classroom Research and Trends from Different Fields of Study. International Review of Research in Open and Distance Learning, Athabasca, 17(3), 113- 340.

233.Zayed, Mostafa Zayed; Abdel Aziz, Ahmed Youssef; \& Mohammed, Atef Mohamed. (2018). The impact of flipping geography class on the development of some geographic skills among the students of the first secondary grade Azhari. Journal of Culture and Development, Issue (126), 206-238.

234.Zengor, Maher Mohammed. (2017). Flipped Classroom environment and its Effect on Developing Intuitive Thinking and Levels of Proportional Reasoning in Mathematise among Intermediate Stage Students of different Cerebral Dominance. Studies in Curriculum and Teaching Methods, Egypt, Issue (220), 16-93. 